\title{
Kualitas Mikrobiologis Se'i yang Dicuring Menggunakan Jus Kulit Buah Naga Merah (Hylocereuspolyrhizus) pada Penyimpanan Suhu Ruang
}

\author{
Theresia I. Purwantiningsih ${ }^{\mathrm{a}}$ dan Kristoforus W. Kia ${ }^{\mathrm{b}}$ \\ ${ }^{a}$ Fakultas Pertanian, Universitas Timor, Kefamenanu, TTU - NTT, Indonesia, email: theresiaicha@ gmail.com \\ ${ }^{b}$ Fakultas Pertanian, Universitas Timor, Kefamenanu, TTU - NTT, Indonesia,email:willykia7l@yahoo.co.id
}

\section{Article Info}

Article history:

Received 11 Januari 2019

Received in revised form 24 Januari 2019

Accepted 25 Januari 2019

DOI:

https://doi.org/10.32938/ja.v4i1.650

Keywords:

Kulit Buah Naga, Se'i, Anti mikroba

\section{Abstrak}

Kulitbuh naga merah (Hylocereus pilyrhizus) mengandung senyawa antibakteri yang dapat menghambat pertumbuhan mikroorganisme. Dengan adanya senyawa antibakteri tersebut, kulit buah naga berpotensi untuk dijadikan bahan pengawet alami, untuk menggantikan penggunaan bahan pengawet kimia seperti Nitrit pada pengolahan se'i (daging asap khas Nusa Tenggara Timur). Hasil penelitian menunjukkan bahwa ekstrak kulit buah naga mampung menghambat pertumbuhan bakteri patogen seperti E.coli ATCC 25922 dan bakteri S.aureus ATCC 25923. Perbedaan perlakuan bakteri patogen yang diberikan berpengaruh nyata terhadap diameter zona hambat aktivitas antibakteri jus kulit buah naga merah $(\mathrm{P}<0.05)$. Penggunaan jus kulit buah naga sebagai bahan curing pada se'i dapat menghambat pertumbuhan bakteri dan memperpanjang masa simpan sampai pada hari ke enam pada suhu ruang. Dapat disimpulkan bahwa penggunaan jus kulit buah naga sebagai bahan curing pada se'i dapat menghambat pertumbuhan bakteri sehingga mampu memperpanjang masa simpan se'i pada suhu ruang.

\section{Pendahuluan}

Seiring perkembangan zaman, terdapat banyak variasi pengolahan pangan asal hewani. Konsumsi pangan olahan produk hasil ternak, yang tidak sehat dan tidak aman untuk dikonsumsi diduga menjadi salah satu kontributor timbulnya penyakit kanker. Hal tersebut diakibatkan keberadaan senyawa berbahaya pada bahan pangan yang terbentuk selama proses pengolahan. Beberapa senyawa berbahaya yang bersifat toksik, mutagenik dan karsinogenik tersebut diantaranya adalah senyawa malonaldehida, nitrosamin, heterosiklikamin (HCA), polisiklik aromatik hidrokarbon (PAH), akrilamida, dan 3-monokloropropan-1,2-diol (3MCPD). Produk olahan pangan kaya akan protein dan lemak seperti produk hasi ternak, jika pengolahannya tidak dilakukan dengan tepat dapat berpotens menimbulkan senyawa berbahaya tersebut, yang berarti memberikan sumbangan terhadap timbulnya penyakit kanker.

Se'i (daging asap khas NTT) merupakan salah satu produk industri hilir dari bidang peternakan yang berpotensi mengandung senyawa berbahaya terutama residu nitrat, nitrosamin dan malonaldehida, jika proses pengolahannya tidak dilakukan dengan tepat. Se'i ini merupakan olahan daging khas NTT yang diperoleh melalui proses curing dan pengasapan. Curing didefinisikan sebagai penambahan garam dapur, gula, bawang putih, lada bubuk, pada daging dengan tujuan memperoleh warna merah yang stabil serta menghasilkan karakteristik yang khas pada daging. Selain itu, pada tingkat produksi komersial proses pembuatan se'i diberi penambahan garam nitrat atau nitrit untuk menghasilkan warna merah dan juga berfungsi sebagai pengawet. Akan tetapi dalam penggunaan garam nitrat atau nitrit pada produk olahan daging dibatasi oleh BPOM No. 36 Tahun 2013 yang mengatakan bahwa, jumlah maksimum nitrit atau nitrat yang diizinkan dalam produk olahan daging adalah $30 \mathrm{mg} \mathrm{kg}^{-1}$ untuk nitrit dan $50 \mathrm{mg} \mathrm{kg}^{-1}$ untuk nitrat. Hal ini karena penggunaan nitrat atau nitrit yang melebihi standar yang ditentukan, dapat menimbulkan masalah kesehatan seperti kanker. Pembatasan penggunaan nitrit dan nitrat juga diatur dalam Peraturan Menteri Kesehatan No. 003 Tahun 2012, yaitu jumlah maksimum nitrit $0.06 \mathrm{mg} \mathrm{kg}{ }^{-1} \mathrm{BB}$ atau nitrat $3.7 \mathrm{mg} \mathrm{kg}^{-1} \mathrm{BB}$ yang dapat dikonsumsi tanpa menimbulkan efek merugikan pada kesehatan.

Penggunaan nitrit atau nitrat sebagai bahan tambahan makanan yang multiguna diharapkan dapat diganti dengan bahan alami berasal dari buah atau tumbuhan yang banyak diteliti fungsi dan komposisinya. Salah satunya adalah kulit buah naga merah yang masih sangat sedikit pemanfaatannya. Pemanfaatan buah naga ini masih terbatas pada daging buahnya saja, sedangkan kulit buah naga yang mencapai $20-30 \%$ dari bobot buah masih belum dimanfaatkan dan dibuang menjadi limbah.

Beberapa penelitian sebelumnya telah menunjukkan potensi dan manfaa kulit buah naga merah karena kandungan senyawa bioaktif dan nilai gizinya. Harivaindaran et al. (2008) telah melakukan analisis potensi zat warna alami pada kulit buah naga merah (Hylocereus polyrhizus) yang mengandung senyawa penghasil warna merah alami pada suhu dan temperatur optimal. Selain itu, fungsi kulit buah naga merah juga diteliti oleh Nurmahani et al. (2012) sebaga antibakteri pada sembilan bakteri patogen makanan akibat senyawa antibakteri pada kulit buah naga merah tersebut. Aktivitas antioksidan kulit buah naga merah juga telah diteliti oleh Luo et al. (2014) mempunyai beberapa senyawa antioksidan yang berfungsi sebagai antioksidan alami.

\section{Metode}

Penelitian ini adalah penelitian eksperimental laboratoris in vitro yang bertujuan untuk menguji kualitas mikrobiologis se'i yang telah dicuring menggunakan jus kulit buah naga merah dan disimpan pada lama penyimpanan 2, 4 dan 6 hari pada suhu ruang, yang dimulai pada bulan November-Desember 2018. Alat dan bahan yang digunakan adalah kulit buah naga merah dan aquades, daging sapi serta alat untuk menguji angka lempeng total bakteri digunakan media PCA. Alat yang digunakan berupa incubator, laminar air flow, serta cawan petri.

\subsection{Pembuatan Se'}

Daging dipotong memanjang dengan ukuran 2,0 - 2,5 cm kemudian dimasukkan dalam wadah dan diberi bahan curing (bumbu, jus kulit buah naga merah 50\% dan nitrat $125 \mathrm{ppm}$ sesuai perlakuan) sambil dilakukan peremasan. Setelah itu daging disimpan pada suhu dingin selama 12 jam kemudian diasap, proses pengasapan menggunakan kayu bakar (kayu kusambi) selama 2 jam. Sampel se'i yang dihasilkan disimpan sesuai perlakuan.

\subsection{Analisis Mikrobiologis Se'i.}

Lima gram sampel se'i disuspensikan ke dalam $45 \mathrm{~mL} \mathrm{NaCl0.85 \% (w/v)}$ steril. Analisis mikrobiologis dilakukan dengan pourplate method menggunakan plate count agar (PCA) untuk uji angka lempeng total bakteri yang tumbuh pada se'i selama masa penyimpanan. Digunakan pengenceran $10^{-4}$ sampai $10^{-6}$ pada semua pengujian. Sampel diinkubasi selama 24 jam pada suhu $37^{\circ} \mathrm{C}$ (AOAC 2005).

\section{Hasil dan Pembahasan}

\subsection{Uji Daya Hambat Bakteri Ekstrak Kulit Buah Naga}

Pengujian aktivitas antibakteri pada ekstrak kulit buah naga merah dilakukan pada dua bakteri patogen, baik bakteri gram positif (Staphylococcus aureus ATCC 25923) yang ditunjukkan pada Gambar 1 maupun bakteri gram negatif (Escherichia coli ATCC 25922) yang ditunjukkan pada Gambar 2. Hasil analisis aktivitas antibakteri dilihat berdasarkan diameter zona hambat ekstrak terhadap pertumbuhan bakteri patogen yang digunakan dalam pengujian ini. Diameter zona hambat yang dihasilkan ekstrak kulit buah naga merah dapat dilihat pada Tabel 1 .

Tabel 1. Diameter zona hambat aktivitas antibakteri jus kulit buah naga merah

\begin{tabular}{lcc}
\hline \multirow{2}{*}{ Perlakuan } & \multicolumn{2}{c}{ Diameter zona hambat $(\mathrm{mm})$} \\
\cline { 2 - 3 } & $0,00 \pm 0,00^{\mathrm{a}}$ & S. aureus \\
\hline Kontrol & $14,82 \pm 0,82^{\mathrm{d}}$ & $0,00 \pm 0,00^{\mathrm{a}}$ \\
Nitrit & $7,46,04 \pm 0,24^{\mathrm{d}}$ \\
Jus kulit buah naga & merah & $11,38 \pm 2,39^{\mathrm{c}}$ \\
\hline
\end{tabular}

Ket : Angka-angka pada kolom yang sama diikuti oleh huruf yang sama tidak berbeda nyata pada taraf uji $5 \%$.

Sapatnekar et al. (2010) menyatakan aktivitas anti mikroba ditunjukkan dengan terbentuknya zona hambat bening dan zona yang berbeda dari area cawan sekitar cawan yang ditumbuhi oleh bakteri indikator yang digunakan. Jus kulit buah naga merah menunjukkan adanya penghambatan terhadap aktivitas bakteri gram positif dan gram negatif. Perbedaan perlakuan bakteri patogen yang diberikan berpengaruh nyata terhadap diameter zona hambat aktivitas antibakteri jus kulit buah naga merah $(\mathrm{p}<0.05)$. Jus kulit buah naga merah memiliki aktivitas penghambatan terbesar pada bakteri patogen S. aureus ATCC25923 dengan diameter zona hambatnya berbeda dengan bakteri patogen lainnya.

Bakteri patogen gram positif, S. aureus ATCC 25923, lebih sensitif terhadap aktivitas antibakteri dari ekstrak kulit buah naga merah. Hal ini didukung oleh Arief et al. (2015) yang menyatakan bahwa bakteri gram positif lebih rentan dibandingkan bakteri gram negatif terhadap aktivitas antibakteri. Bakteri gram positif tidak memiliki dinding lipoprotein seperti bakteri gram negatif yang mampu membatasi masuknya zat anti mikroba ke dalam sel bakteri (Tenore et al., 2012).

Penelitian Faridah et al. (2015) menunjukkan bahwa kandungan betalians pada ekstrak kulit buah naga merah memiliki aktivitas antibakteri yang lebih baik pada bakteri S. aureus dibanding E. coli. Selain itu, Amalia et al. (2015) juga melakukan uji aktivitas antibakteri ekstrak kulit buah naga merah pada $S$. aureus menyatakan bahwa senyawa antibakteri terpenoid pada ekstrak kulit buah naga merah mampu menghambat pertumbuhan bakteri ini. Luo et al. (2014) menambahkan bahwa kandungan terpenoid terdiri atas $\beta$-amirin dan a-amirin, 
yang menurut hasil isolasi Tahany et al. (2010) terbukti menghambat pertumbuhan bakteri $S$. aureus.

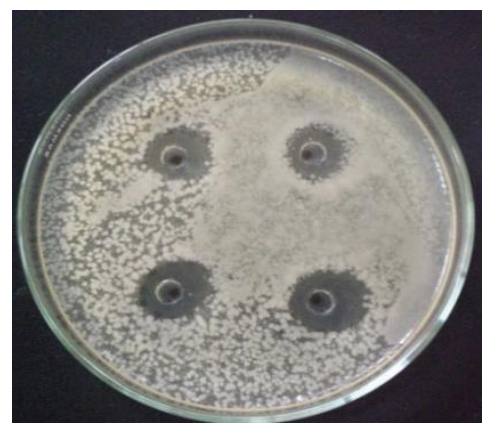

Gambar 1. Zona hambat bening pada bakteri uji S.aureus ATCC 25923

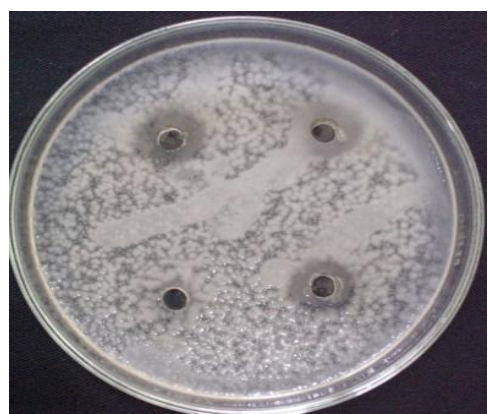

Gambar 2. Zona hambat bening pada bakteri uji E.coli ATCC 25922

\subsection{Kualitas Mikrobiologis Se'i Selama Penyimpanan}

Dari Tabel 2, dapat dilihat bahwa pada penyimpanan hari kedua terdapat sejumlah bakteri pada ketiga perlakuan. Sampel se'i yang tidak diberi perlakuan (kontrol) terdapat 1,43 log cfu/g, perlakuan nitrit $0,12 \mathrm{log} \mathrm{cfu} / \mathrm{g}$ dan perlakuan jus kulit buah naga $0.18 \log \mathrm{cfu} / \mathrm{g}$. Pada penyimpanan hari keempat angka lempeng total pada se'i yang tidak diberi perlakuan sejumlah $2,48 \log \mathrm{cfu} / \mathrm{g}$, nitrit $0,21 \log \mathrm{cfu} / \mathrm{g}$ dan pada perlakuan jus kulit buah naga $0,32 \log \mathrm{cfu} / \mathrm{g}$. Penyimpanan hari keenam pada penelitian ini menunjukkan bahwa angka lempeng total bakteri pada se'i menunjukkan jumlah 3,38 log cfu/g, 0,46 log $\mathrm{cfu} / \mathrm{g}$ pada perlakuan nitrit dan $1,27 \mathrm{log} \mathrm{cfu} / \mathrm{g}$ pada perlakuan jus kulit buah naga.

Pada setiap perlakuan terjadi peningkatan jumlah total mikroba. Perlakuan nitrit dan kulit buah naga menunjukkan adanya penghambatan pada pertumbuhan mikroorganisme pada se'i. Meskipun jus kulit buah naga mampu menghambat pertumbuhan mikroba pada se'i akan tetapi dari segi kualitatif, penggunaan jus kulit buah naga lebih dianjurkan. Penggunaan jus kulit buah naga dianggap lebih aman dikarenakan jus kulit buah naga adalah bahan alami dan mengandung antioksidan yang baik bagi tubuh dan tidak memiliki efek samping pada tubuh.

Angka lempeng total bakteri pada setiap perlakuan masih menunjukkan angka yang aman untuk dikonsumsi. Jumlah total mikroba ini diduga mengalami penghambatan selain karena adanya bahan pengawet yang diberikan, proses pengasapan pada saat pemanggangan juga dapat mengurangi kadar air pada se'i. Keberadaan air pada bahan pangan merupakan salah satu faktor yang dapat mempengaruhi pertumbuhan mikroorganisme.

Tabel 2. Kualitas Mikrobiologis Se'i Selama Penyimpanan

\begin{tabular}{ccccc}
\hline & Perlakuan & \multicolumn{3}{c}{ Waktu Penyimpanan (hari) } \\
\cline { 2 - 5 } & & 2 & 4 & 6 \\
\hline \multirow{2}{*}{ TPC } & Kontrol & $1,43 \pm 0,37$ & $2,48 \pm 0,12$ & $3,38 \pm 0,24$ \\
$(\log \mathrm{cfu} / \mathrm{g})$ & Nitrit & $0,12 \pm 0,16$ & $0,21 \pm 0,58$ & $0,46 \pm 0,35$ \\
& JKBN & $0,18 \pm 0,21$ & $0,32 \pm 0,16$ & $1,27 \pm 0,30$ \\
\hline
\end{tabular}

\section{Simpulan}

Dari hasil yang diperoleh diatas maka dapat disimpulkan bahwa penggunaan jus kulit buah naga sebagai bahan curing pada se'i dapat menghambat pertumbuhan bakteri sehingga mampu memperpanjang masa simpan se'i pada suhu ruang.

\section{Pustaka}

AOAC. 2005. Official Methods of Analysis of AOAC International $18^{\text {th }}$ Edn. AOAC International., Gaithersburg, MD., USA., ISBN-13-9780935584752

Amalia S. Wahdaningsih S, Untari EK. 2015. Antibacterial activity testing of nhexane fraction of red dragon (Hylocereuspolyrhizus Britton \& Rrose) fruit peel On Staphylococcus aureus ATCC 25923. Traditional Med J. 19(2):9196.

Arief, Budiman C, Jenie BSL, Andreas E, Yuneni A. 2015. Plantaricin IIA1A5from Lactobacillus plantarum IIA-1A5 displays bactericidal activity against Staphylococcus aureus. Beneficial Microbes, 6(4):603-613.
BPOM RI. 2013. Peraturan Kepala BPOM RI No 36 Tahun 2013 Tentang Batas Maksimum Penggunaan Bahan Tambahan Pangan Pengawet, Menkumham RI. Jakarta.

Faridah A, Holinesti R, Syukri D. 2015. Betalains from red pitaya peel (Hylocereus polyrhizus): extraction, spectrophotometric and HPLC-DAD identification, bioactivity and toxicity screening. Pakistan J. Nutr. 14 (12):976-982

Harivaindaran KV, Rebecca OPS, Chandran S. 2008. Study of optimal temperature, $\mathrm{pH}$ and stability of dragon fruit (Hylocereus polyrhizus) peel for use as potential natural colorant. Pakistan J. Biol Sci, 11 (18):22592263.

Luo H, Cai Y, Peng Z, Liu T, Yang S. 2014. Chemical composition and in vitro evaluation of the cytotoxic and antioxidant activities of supercritical carbon dioxide extracts of pitaya (dragon fruit) peel. Chem Central. J, 8 (1):2-7.

Menteri Kesehatan RI. 2012. Peraturan Menteri Kesehatan Republik Indonesia Nomor 003 Tahun 2012 Tentang Bahan Tambahan Pangan, POM RI, Jakarta: 21.

Nurmahani, M.M., Osman, A., Abdul Hamid, A., Mohamad Ghazali, F. dan Pak Dek, M.S. Short Communication Antibacterial Property of Hylocereus polyrhizus and Hylocereus undatus Peel Extracts. 2012. Int. Food Res. J, 19(1):77-84.

Sapatnekar NM, Patil SN, Aglave BA. 2010. Extraction of Bacteriocin and Study of Its Antagonistic Assay. IJ Biotech Biochem, 6: 865-870.

Tahany MAA, Hegazy AK, Sayed AM, Kabiel HF, El-Alfy T, El-Komy SM. 2010. Study on combined antimicrobial activity of some biologically active constituents from wild Moringa peregrine Forssk. J. Yeast and Fungal Resh, 1(1):015-024.

Tenore GC, Novellino E, Basile A. 2012. Nutraceutical potential and antioxidant benefits of red pitaya (Hylocereus polyrhizus) extracts. J. Functional Food, 4:129-136. 